\title{
PCR amplification of a middle repetitive element detects larval stone crabs (Crustacea: Decapoda: Menippidae) in estuarine plankton samples
}

\author{
J. G. MaKinster, J. E. Roberts, D. L. Felder, C. A. Chlan, M. Boudreaux, \\ A. L. Bilodeau, J. E. Neigel*
}

Department of Biology, University of Louisiana at Lafayette, PO Box 42451, Lafayette, Louisiana 70504, USA

\begin{abstract}
Planktonic larval dispersal and recruitment can be major determinants of the structure and dynamics of marine communities. However, these processes have been difficult to study because of their natural variability and the limitations of methods used to collect and analyze plankton samples. In particular, the use of microscopy to determine the composition of plankton samples is timeconsuming and often limited by a lack of reliable morphological characters for species identification. The need for methods of greater accuracy and efficiency has led to the development of molecular approaches to plankton analysis, including detection by DNA hybridization, amplification of DNA from plankton samples by the polymerase chain reaction (PCR) and taxonomic characterization by ribosomal DNA sequence analysis. Here we describe a PCR-based method that detects larval crabs in estuarine plankton samples. This technique is unusually expedient and relatively cost-effective. It is based on the detection of a middle repetitive sequence characteristic of the stone crab Menippe mercenaria, as well as the closely related species $M$. adina. Amplification by PCR of a 585 base pair region of this sequence from plankton samples accurately indicates the presence of either species. Because of the high abundance of this sequence in the genome of Menippe, single larvae can be detected in typical plankton samples. Unlike methods based on 'universal' sequences (rRNA or regions of the mitochondrial genome), the amplification of a PCR product of the expected size is a reliable indication of the presence of the target species, and no further characterization is necessary. This technique is intended to facilitate the large-scale processing of plankton samples that is necessary for accurate determination of the temporal and spatial distributions of individual species in plankton communities.
\end{abstract}

KEY WORDS: Plankton - Larval ecology - Middle repetitive DNA - Estuarine PCR - Crustacea . Menippe

\section{INTRODUCTION}

It is now widely recognized that the supply of planktonic larvae available for recruitment can influence the distribution and abundance of benthic adult populations (Gaines \& Roughgarden 1985, Gaines et al. 1985, Lewin 1986, Young 1987). This has led to renewed interest in the ecology of planktonic larvae and their transport by near-shore oceanographic processes (Grosberg \& Levitan 1992, Gaines \& Bertness 1993, Todd 1998). However, studies of the distributions of plank-

-Addressee for correspondence. E-mail: jneigel@usl.edu tonic organisms are often limited by the labor required to determine the presence and abundance of particular taxa in large numbers of field-collected samples (Silberman \& Walsh 1992, Fuhrman et al. 1994, MedeirosBergen et al. 1995). Identification of larvae can be complicated by either a lack of morphological differentiation between taxa or phenotypic plasticity within taxa (Smith 1977, Medeiros-Bergen et al. 1995). Phenotypic plasticity of larvae may be a source of bias in the analysis of plankton samples because it may reflect responses to environmental factors such as food (Biodron-Metairon 1988), source of water (Wilson \& Armstrong 1961) or temperature (Shirley et al. 1987). Consequently, the use of light microscopy and traditional 
morphological identification to analyze plankton samples can be tedious and subjective.

Molecular techniques have been used to distinguish among bacterioplankton and the planktonic larvae of metazoan invertebrates (Coffroth \& Mulawka 1995, Medeiros-Bergen et al. 1995, $\operatorname{Lim}$ 1996). One of the earliest such studies, by Giovannoni et al. (1990), used PCR amplification and sequencing of large subunit rDNA (LSRDNA) sequences, often referred to as '16S sequences', to identify 3 distinct lineages of bacterioplankton present in the Sargasso Sea. Comparisons of LSRDNA sequences have also been used to distinguish the larvae of closely related marine invertebrate taxa (Ward et al. 1990, Olsen et al. 1991, Fuhrman et al. 1992, 1994).

An alternative to complete analysis of LSRDNA DNA sequences for species identification is the use of LSRDNA hybridization probes (Rehnstam et al. 1993, Fuhrman et al. 1994, Medeiros-Bergen et al. 1995). These probes specifically hybridize with the DNA of a target genus or species. Medeiros-Bergen et al. (1995) used this approach to identify 3 morphologically indistinguishable species of sea cucumber larvae. Although this method offers the advantages of increased sensitivity, it is labor-intensive and costly.

Randomly amplified polymorphic DNA (RAPD) analysis (Williams et al. 1990) requires fewer manipulations and is less expensive than hybridization analysis or direct sequencing of PCR products. RAPD polymorphisms have been used as species-specific markers for 5 species of gorgonian corals (Coffroth \& Mulawka 1995). This technique is expedient because only the sizes of PCR products need to be determined, which can be accomplished easily by agarose gel electrophoresis. However, the reproducibility of RAPD analysis may be compromised by variable sample conditions, and the genetic basis for the observed polymorphisms is generally unknown (reviewed by Fritsch $\&$ Reiseberg 1996). These limitations make this method unsuitable for the analysis of marine plankton samples. Plankton samples are subjected to variable collection and preservation conditions that would reduce the reproducibility of RAPD analysis. More importantly, plankton samples typically include a diverse array of species, each of which could potentially produce confounding PCR products in a RAPD analysis.

Middle repetitive sequence elements have seldom been used for species identification, although their general characteristics suggest they may be suitable for this purpose. Middle repetitive sequences are defined as sequences present in $10^{3}$ to $10^{5}$ copies genome $e^{-1}$ (Hardman 1986), and are typically dispersed throughout a genome (Felger \& Sperlich 1989). Divergence in the middle repetitive sequences of different species is often greater than divergence in other se- quences used for species identification, including mitochondrial DNA and nuclear gene sequences. As a result, homologous repetitive DNA sequences can generally be detected in closely related species by DNA hybridization, but not in species that have diverged for more than about 5 million yr (Felger \& Hunt 1993). Therefore, we expect most middle repetitive sequences to be characteristic of either species or recently evolved genera. Among Crustacea, families of repetitive elements have been found in multiple species, but the similarity of these sequences decreases rapidly with taxonomic divergence (Graham \& Skinner 1973). Recent analysis of LSRDNA sequences from the 2 Menippe species that occur and hybridize in the Gulf of Mexico ( $M$. adina and $M$. mercenaria) indicates that they probably separated less than 2 million yr before present (Schneider-Broussard et al. 1998). Thus, we expect a middle repetitive sequence from $M$. adina to be characteristic of this species pair.

In the present study, PCR amplification of a middle repetitive element was used for specific detection of DNA from Menippe adina and $M$. mercenaria under a variety of conditions, including DNA in mixtures obtained from plankton samples. Our methods are intended as a less costly and less laborious alternative to either microscopic examination or methods that require DNA sequence characterization.

\section{MATERIALS AND METHODS}

Isolation and characterization of a middle repetitive sequence from Menippe. Stone crabs ( $M$. adina and $M$. mercenaria) were trapped in wire crab pots from 3 locations by local fisherman and by D.L.F. $M$. adina specimens were collected from upper Terrebonne Bay near Cocodrie, Louisiana; $M$. mercenaria were collected from Rookery Bay, near Naples, Florida, from Harbor Branch Marine Institute harbor, north of Fort Pierce, Florida, and from a locale near Brunswick, Georgia. Total genomic DNA was isolated from fresh tissues of $M$. adina and $M$. mercenaria. DNA from 1 specimen of $M$. adina was used to construct a genomic library in the plasmid pUC19 (Maniatis et al. 1982, Neigel et al. 1991). One recombinant plasmid, pMACC36, contained the middle repetitive sequence used in this study (henceforth designated MACC36). The sequence of MACC36 was determined by the dideoxy method (Sanger et al. 1977) and the primers shown in Table 1. The complete sequence of MACC36 is available from GenBank (Accession no. AF058687)

The sequence of MACC 36 was used to design PCR primers (36F and 36R in Table 1) for the amplification of related sequences from both Menippe adina and $M$. mercenaria. PCR amplifications of the expected $1.7 \mathrm{~kb}$ 
Table 1. PCR primer sequences used for sequencing MACC36 and for detection of homologous sequences in Menippe mercenaria and $M$. adina

\begin{tabular}{|c|c|}
\hline Primer & Sequence \\
\hline \multicolumn{2}{|c|}{ MACC36 sequencing } \\
\hline $36 \mathrm{~F}$ & AATGAGCGTCTTCTGAGCATATAG \\
\hline $36 \mathrm{R}$ & GGATCTTGAGGAATGCACATTCTT \\
\hline $36 \mathrm{~F} 3$ & GCTCAAGTCTGCACAAAT \\
\hline $35 \mathrm{R} 3$ & GAGAGTCTTCTAAGGAGGAGGCGTTGA \\
\hline $36 \mathrm{~F} 4$ & CATAATTGTCGATAGTAAGT \\
\hline \multicolumn{2}{|c|}{ Larval detection } \\
\hline $36 F 5$ & CACACACTTCTTGAGAAAAGG \\
\hline $36 \mathrm{R} 5$ & GTTCTTITTTGTTTCCTCCAC \\
\hline
\end{tabular}

sequences homologous to MACC36 were routinely obtained from genomic DNA after reaction conditions were optimized. These products were cloned by TA ligation into the pCRII cloning vector (Invitrogen Corp.). Fifteen recombinant plasmids with the expected insert size were mapped using 3 restriction endonucleases (EcoRI, HindIII and Pstl) and compared to the pMACC36 insert. Seven of these inserts were also partially sequenced using the dideoxy method (Sanger et al. 1977) and are referred to as TACC36 sequences.

The copy number of sequences homologous to MACC36 was estimated by hybridization of an MACC36 probe to genomic DNA from Menippe adina and $M$. mercenaria. A Bio-Rad slot blot manifold (Bio-Rad 2000) was used to apply genomic DNA samples and MACC36 standards to a nitrocellulose membrane. Across each row of slots, $100 \mathrm{ng}$ aliquots of genomic DNA were alternated with standard amounts of purified MACC 36 that ranged from $6.3 \mathrm{pg}$ to $2 \mathrm{ng}$ in 2 -fold increments, with $100 \mathrm{ng}$ of salmon sperm DNA added to each standard to provide a uniform background of non-target DNA. Three replicates of each sample were included to control for random variation in hybridization intensity across the membrane. Non-radioactive labeling of the probe and immunological detection were performed using the 'Genius DNA Labeling and Detection Kit' (Boehringer Mannheim) according to the manufacturer's directions. The probe contained $3 \mu \mathrm{g}$ of digoxigenin-labeled pMACC 36 in $10 \mathrm{ml}$ of prehybridization solution $(5 \times \mathrm{SSC}, 0.1 \% \mathrm{~N}$-lauroylsarcosine, $0.02 \%$ SDS, $1 \%$ blocking reagent), and hybridization was performed overnight at $69^{\circ} \mathrm{C}$.

Larval detection. Stone crab first zoeal stage larvae (Z1 larvae) were hatched from eggs of ovigerous female specimens of Menippe adina and $M$. mercenaria collected at Cocodrie and Fort Pierce respectively. To provide a standard non-Menippe control,

naupliar larvae of Artemia sp. were cultured from cysts (Red Jungle Brand O.S.I ) at $23^{\circ} \mathrm{C}$ in $23 \%$ salinity artificial seawater. Mixtures of estuarine zooplankton from Lake Pelto, LA, were collected with a $0.5 \mathrm{~mm}$ mesh plankton net of mouth dimensions $0.45 \times 0.2 \mathrm{~m}$ towed at $\sim 1 \mathrm{~m} \mathrm{~s}^{-1}$ along a fixed $240 \mathrm{~m}$ path. All larvae and plankton were gently strained, rinsed with ethanol and placed immediately in 95 to $100 \%$ ethanol. Prior to DNA isolation, larvae and plankton were placed on Miracloth (Calbiochem ${ }^{\otimes}$ ) and rinsed with deionized water. DNA was isolated following the phenol:chloroform DNA extraction procedure of Palumbi et al. (1991).

For detection of larval DNA, a portion of the MACC36 sequence was amplified using the primers $36 \mathrm{~F} 5$ and 36R5 (Table 1). Amplifications were performed in a Perkin-EImer N801-0150 DNA Thermal Cycler: 1 cycle at $94^{\circ} \mathrm{C}$ for $1 \mathrm{~min} ; 35$ cycles of $94^{\circ} \mathrm{C}$ for $1 \mathrm{~min}$, $53^{\circ} \mathrm{C}$ for $1 \mathrm{~min}$, ramp for $2 \mathrm{~min}, 72^{\circ} \mathrm{C}$ for $90 \mathrm{~s} ; 1$ cycle at $72^{\circ} \mathrm{C}$ for $5 \min _{i} 15^{\circ} \mathrm{C}$ soak. The $25 \mu$ reactions contained final concentrations of $2 \mathrm{mM}$ dNTP, $2 \mu \mathrm{M}$ of each primer, $1 \times$ Perkin Elmer's PCR Buffer with $1.5 \mathrm{mM} \mathrm{MgCl}_{2}, 1 \mathrm{U}$ of Amplitaq Gold ${ }^{\mathrm{TM}}$ polymerase, and $1 \mu \mathrm{l}$ of template DNA. Sizes of amplification products were determined by electrophoresis of $10 \mu \mathrm{from}$ each reaction on $2 \%$ agarose gels.

To test for the specificity of detection, reactions were run with 20 to $100 \mathrm{ng}$ of DNA isolated from other brachyuran crabs, from Artemia, or from mixed plankton samples that did not contain larval Menippe (Table 2). All PCRs with DNA from non-target species were performed using an annealing temperature of $45^{\circ} \mathrm{C}$ (rather than $53^{\circ} \mathrm{C}$ ) to lower the stringency of primer annealing and thus provide a more conservative test of non-specific amplification. The suitability of non-target DNA for PCR was verified by amplification of a LSRDNA sequence from each sample using the procedure of Palumbi et al. (1991) for the primers 16 sar-L and 16 sbr-H.

The sensitivity of the PCR assay was tested with template DNA from Menippe in amounts ranging from $10 \mathrm{pg}$ to $100 \mathrm{ng}$ per $25 \mathrm{\mu l}$ reaction. This range was also used in reactions to which either $10 \mathrm{ng}$ of naupliar Artemia DNA or $10 \mathrm{ng}$ of mixed estuarine plankton

Table 2. Non-target DNA samples used as negative controls for PCRs to test for the specificity of the 36F5 and 36R5 primers as diagnostics for Menippe. Between 20 to $100 \mathrm{ng}$ of DNA was used in each reaction

$\begin{array}{ll}\text { Panopeus americanus } & \text { Sesarma reticulatum } \\ \text { P. simpsoni } & \text { Callinectes sapidus } \\ \text { P. lacustris } & \text { Ocypode quadrata } \\ \text { Eurypanopeus dissimilis } & \text { Artemia sp. } \\ \text { E. depressus } & \text { Estuarine mixed plankton } \\ \text { Cataleptodius floridanus } & \end{array}$

Panopeus americanus P. simpsoni

Eurypanopeus dissimilis Cataleptodius floridanus
Artemia sp.
Estuarine mixed plankton 
Table 3 Sources and dilutions of Menippe DNA samples used to test the sensitivity of Menippe-specific PCR amplification across the geographic range of Menippe. DNA from non-target sources were added to test for interactions or interference between DNA from Menippe and DNA from other taxa. Successful amplifications of the sequence (585 bp) from Menippe: +. EP: estuarine mixed plankton

\begin{tabular}{|lcccccc|}
\hline Sample & $100 \mathrm{ng}$ & $10 \mathrm{ng}$ & $1 \mathrm{ng}$ & $100 \mathrm{pg}$ & $10 \mathrm{pg}$ & $1 \mathrm{pg}$ \\
\hline M. mercenaria (Brunswick, GA) & + & + & + & + & + \\
M. mercenaria (Fort Pierce, FL) & + & + & + & + & + & + \\
M. adina (Cocodrie, LA) & + & + & + & + & + & + \\
M. mercenaria (FL) and 10 ng Artemia DNA & + & + & + & + & + \\
M. mercenaria (FL) and 10 ng EP DNA & + & + & + & + & + \\
\hline
\end{tabular}

DNA were added, to test for interactions or interference between DNA from Menippe and non-target species (Table 3). An amplification was considered successful if a band could be easily visualized on a UV transilluminator, which required a product DNA concentration of at least $5 \mathrm{ng} \mathrm{\mu l}^{-1}$.

Nauplii of Artemia were used to provide a standard background of larvae from a non-target species against which larval Menippe could be detected. Concentrated suspensions of nauplii were removed from culture, rinsed with deionized water, drained of excess liquid on filter paper, and divided into $100 \mu$ volume aliquots. Each aliquot contained approximately 1500 to 2000 nauplii. A similar procedure was used for the preparation of $100 \mu \mathrm{l}$ aliquots of estuarine plankton that were collected during times of the year when larval Menippe are not present. Z1 larval Menippe were then added to these aliquots prior to DNA isolation. Negative control PCRs (without template DNA) were prepared in parallel with each set of PCRs to test for contamination of reagents and buffers.

\section{RESULTS}

\section{Isolation and characterization of a middle repetitive sequence from Menippe}

The nucleotide sequence of MACC36 did not resemble any published sequences and did not appear to encode a protein. A BLAST search (Altschul et al. 1990) of the GenBank database did not locate any sequences with statistically significant matches. The longest open reading frame found in conceptual translations of MACC 36 was only 372 bp (base pairs). To examine the possibility that the sequence could be a retroviral element, conceptual translations of all reading frames were compared with known reverse transcriptase peptide sequences, which contain several highly conserved amino acid residues at specific positions (Finnegan 1989). These conserved residues were not found in any reading frame for MACC36.
Sequences from Menippe adina and $M$. mercenaria that are homologous to MACC36 were variable and did not exhibit species-specific characteristics. Fifteen individual TACC36 sequences from $M$. adina and $M$. mercenaria were amplified by PCR, cloned and compared by restriction mapping (Roberts 1995). All except 3 appeared to share at least 1 restriction site with others, but they varied in the number and position of individual sites as well as overall length. From one individual 8 distinct restriction maps were observed among 9 sequences, and from another individual all 4 sequences had distinct restriction maps. The isolation of more than 2 sequences from single individuals indicates that sequences homologous to MACC36 are present in multiple copies per genome. Seven of the TACC36 clones were partially sequenced from each end. Between 111 and 186 bp were obtained for each sequence. All were clearly homologous to MACC 36. Divergence between sequences homologous to MACC36 and a consensus sequence ranged from 0.9 to $6.3 \%$, and averaged $2.7 \%$. In addition, up to 8 insertions/deletions (indels) were observed in comparisons with a consensus sequence, including up to 7 that would cause frameshifts within a coding region (Roberts 1995). There were no characteristics that could be used to distinguish TACC36 sequences isolated from $M$. adina from those isolated from $M$. mercenaria.

Estimates of the copy number of sequences homologous to MACC36 were obtained by quantification of the hybridization of a MACC36 probe to genomic DNA samples from Menippe adina and $M$. mercenaria. There was some variation in hybridization intensity among genomic DNA samples from different individuals, but replicate extractions were not performed to determine if this reflected actual variation in copy number. From a comparison of hybridization intensities of the genomic DNA samples with the MACC36 standards, we estimated the mass of DNA in each sample that consisted of sequences homologous to MACC 36. These estimates were converted to estimates of copy number (Table 4 ) for a sequence $3.0 \mathrm{~kb}$ in length (Roberts 1995) and a haploid genome size of 
Table 4. Copy number estimates of the MACC36 sequences for several genomic DNAs. Copy number of sequences homologous to MACC36 was estimated by hybridization of a nonradioactively labeled probe to EcoRI digested genomic DNA from Menippe adina and $M$. mercenaria. A Bio-Rad slot blot manifold (Bio-Rad 2000 $\left.{ }^{(}\right)$was used to apply genomic DNA samples and MACC36 standards to a nitrocellulose mernbrane. Three replicates of each sample were included to control for variation in hybridization intensity

\begin{tabular}{|lrrc|}
\hline Species & Ind. & Avg. copy no. & Range \\
\hline Menippe adina & 55 & 8300 & $6800-9600$ \\
M. mercenaria & 43 & 12400 & $9800-14200$ \\
M. mercenaria & 95 & 18500 & $18000-19000$ \\
M. mercenaria & 96 & 15200 & $11400-18500$ \\
M. mercenaria & 101 & 15400 & $14000-16400$ \\
\hline
\end{tabular}

tions, down to $10 \mathrm{pg}$ of DNA per reaction (Table 3), which represents less DNA than would be present in 2 diploid cells. Furthermore, amplifications were successful over the same range when $10 \mathrm{ng}$ of DNA from either Artemia or from mixed plankton samples was added to each reaction. Thus, even when present at 1000 -fold greater concentration, the presence of nontarget species DNA does not compromise the sensitivity of this assay.

DNA isolated from mixtures of plankton could differ substantially in quality from the purified DNA used in the experiments described above, and DNA quality could limit the sensitivity of a PCR-based assay. To investigate this possibility, we isolated total DNA from mixtures that included between 1 and 200 larval Menippe and a substantially greater biomass of either
$2.7 \mathrm{pg}$ (Rheinsmith et al. 1974). The average of these estimates was $9.3 \times$ $10^{4}$ copies.

\section{Larval detection}

The specificity of the primers $36 \mathrm{~F} 5$ and 36R5 for Menippe was tested in PCRs with DNA from other crustacean species, including other representatives of the superfamily Xanthoidea and in plankton samples that did not include larval Menippe. None of these DNA samples produced amplification products (Table 2). This cannot be attributed to general unsuitability of the samples for PCR because LSRDNA sequences were successfully amplified from each DNA sample. While we cannot extrapolate these results to species that have not been tested, our results show that amplification products are not obtained from crustaceans in general, from several xanthoid species that are likely to occur with Menippe, or from a diverse array of organisms found in estuarine plankton samples.

The sensitivity of our PCR assay was first determined for genomic DNA isolated from adult specimens of Menippe adina and $M$. mercenaria, and purified by ultracentrifugation. Amplifications were consistently successful over a $10^{4}$-fold range of DNA template concentra-
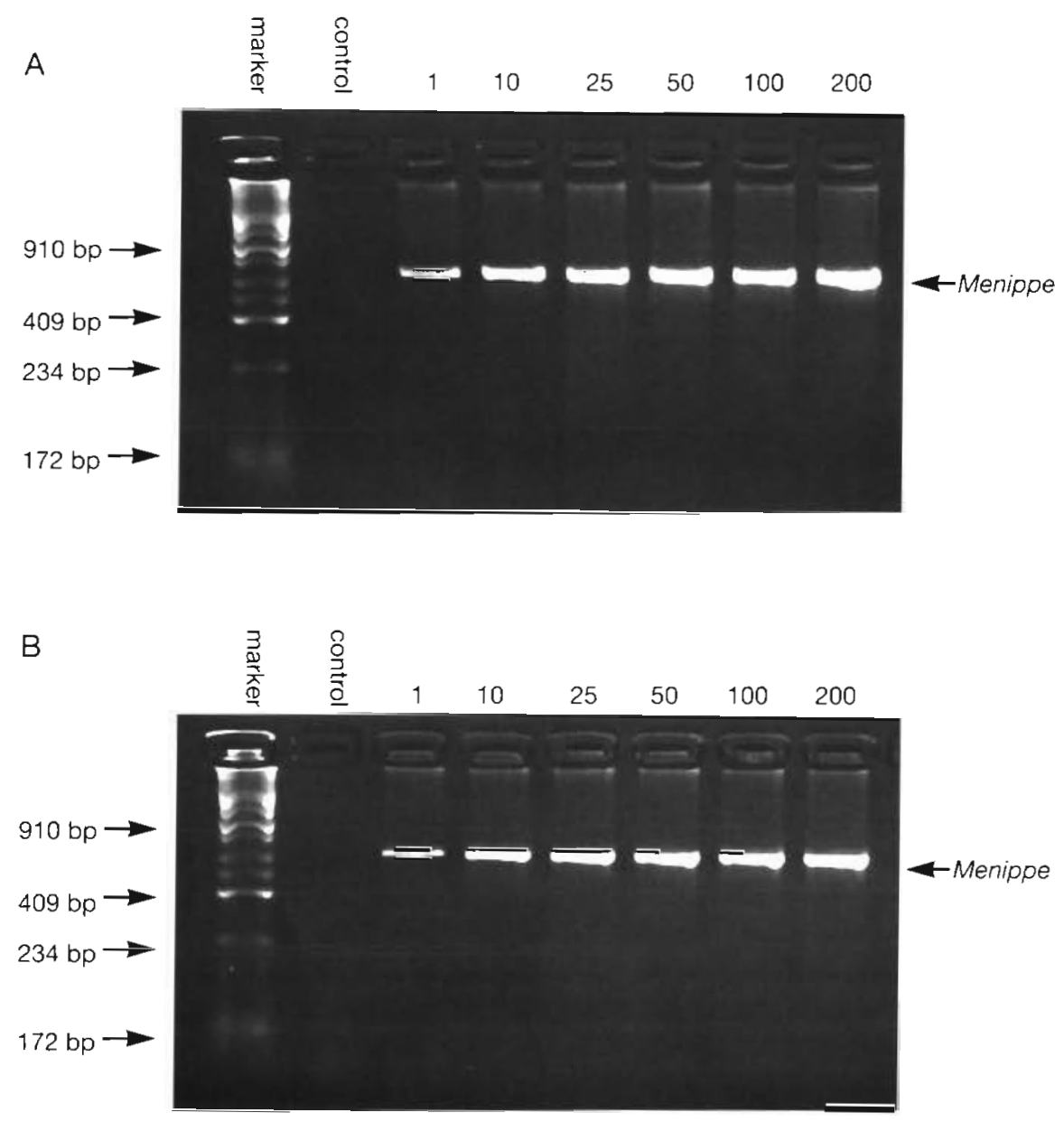

Fig. 1 Agarose gel electrophoresis of Menippe-specific PCR products. $100 \mu \mathrm{l}$ aliquots of naupliar Artemia and estuarine plankton were prepared, and 1, 10 $25,50,100$ or 200 first stage zoeal larvae from Menippe were added to these aliquots prior to DNA isolation. PCR products of target DNA from Menippe were identified for increasing numbers of zoeal larvae detected in the presence of (A) naupliar Artemia and (B) estuarine plankton. Lengths in base pairs are indicated for size standard fragments from pUC 18 digested with Ddell (Lane 1) 
naupliar Artemia (between 1500 and 2000 nauplii), or field collected samples of estuarine plankton that contained assorted non-target species of crustacean larvae and other zooplankton. In every case, amplifications were successful (Fig. 1). These results demonstrate that the PCR assay is sensitive enough to detect even a single larval Menippe that is greatly diluted in a sample of mixed zooplankton.

\section{DISCUSSION}

Although middle repetitive DNA sequences have been characterized from many species, they are seldom used as phylogenetic or population genetic markers. Middle repetitive sequences have been of interest to evolutionary biologists primarily because many of them are transposable elements (Spradling \& Rubin 1981, Georgiev et al. 1982). For example, about half of the middle repetitive DNA in the genome of Drosophila melanogaster is comprised of about 30 families of transposable elements (Spradling \& Rubin 1981). Functional transposable elements may have distinctive characteristics, such as terminal repeats, and at least some elements must encode a transposase. We cannot determine if the family of sequences represented by MACC36 has terminal repeats because our sequence represents only a $2 \mathrm{~kb}$ portion of a canonical sequence that is at least $3 \mathrm{~kb}$ in length. However, the degree of variation and the presence of numerous indels found in comparisons of homologous TACC36 sequences suggest that these sequences do not encode functional proteins

Middle repetitive sequences are of limited usefulness for phylogenetic inference because they are usually restricted to one or a few species and often exhibit unusual modes of evolution. However, the characteristics of the MACC36 family of sequences made it a useful target for the larval detection assay described here. The length and complexity of MACC36 allowed us to design PCR primers that appear to be specific for Menippe and result in the amplification of a product of convenient size. The sequence appears to be unconstrained by a protein coding function, which may explain the variation we observed between members of the sequence family and its absence from closely related taxa. The high copy number of this sequence allows it to be detected easily in amounts of genomic DNA that correspond to only a few cells. Under practical conditions, a single $\mathrm{Z} 1$ larva can be detected in a plankton sample.

It should be possible to isolate repetitive sequences that have properties similar to MACC36 for the detection of other planktonic species. In length and copy number, MACC36 is similar to a middle repetitive sequence isolated from the land crab Gecarcinus lateralis by Fowler et al. (1985). This sequence was found to have a length of $2.1 \mathrm{~kb}$ (LaMarca et al. 1981) and a copy number of approximately $1.6 \times 10^{4}$ per haploid genome (Skinner et al. 1982). Restriction analysis of independent clones showed similar restriction patterns in $70 \%$ of the sequences, but $30 \%$ of the sequences had multiple arrangements (Stringfellow et al. 1985). Like MACC36, this sequence exhibits length polymorphism, insertions and deletions, and point mutations. Highly repetitive sequences (those present at greater than $10^{5}$ copies per genome) may generally be too short to be useful for taxon-specific detection. However, Bilodeau and co-workers (Bilodeau et al. 1999) identified a sequence present at $5 \times 10^{5}$ copies per genome that is approximately 600 bases in length, and appears to be specific for the grapsid crab genus Sesarma.

Because of their high abundance, repetitive sequences can be isolated from very small genomic libraries. Our experience suggests that 10 to 20 plasmids with insert sizes of 3 to $5 \mathrm{~kb}$ should be sufficient. Southern blot analysis (Southern 1975) can be used to both estimate copy number and roughly determine the size of the repeat. Some experimentation with the design of PCR primers may be useful; we found that the sensitivity of our assay differed considerably for different primer pairs (data not shown). In our experience, amplification products of about 500 bp are ideal for detection of a target sequence. They can usually be distinguished from non-specific amplification products, which are generally smaller, but are not so large as to be difficult to amplify from partially degraded DNA.

Detection of a specific genus or species by amplification of a diagnostic middle repetitive sequence is relatively inexpensive and efficient. DNA isolation, PCR amplification, and gel electrophoresis can be performed simultaneously on a large number of samples. Most significantly, with suitable controls for the specificity and reproducibility of the assay, additional characterization of the diagnostic PCR products should be unnecessary. In contrast, if DNA sequencing is used to determine whether a specific sequence is present in a mixture generated by PCR, it is necessary to first isolate single sequences by cloning and then sequence each clone individually (e.g. Fuhrman et al. 1994). Even techniques that employ DNA hybridization rather than sequencing to characterize LSRDNA, rDNA, and other sequences that are amplified with 'universal' primers require additional steps; these include the transfer of PCR products to a membrane, hybridization with a diagnostic probe, and visualization of the hybridization signal (MedeirosBergen et al. 1995j. 
The sensitivity of detection afforded by the use of repetitive sequences is unlikely to be matched by methods based on low copy number nuclear sequences or mitochondrial sequences. For example, successful PCR amplification of the mitochondrial small subunit ribosomal RNA gene from a variety of organisms typically requires at least 10 to $20 \mathrm{ng}$ of genomic DNA (Palumbi et al. 1991), which is 1000 -fold more DNA than was required for our assay. We have found that about $50 \mathrm{ng}$ of genomic DNA can be isolated from a single Z1 larva of Menippe by routine methods. However, in a typical application only a small proportion of the total DNA isolated from a plankton sample is used as a template for each PCR. Thus, it is unlikely that a mitochondrial sequence would be detected from a single Z1 larva of Menippe present in a plankton sample.

We have demonstrated that larval Menippe can be detected with extreme sensitivity by PCR amplification of a repetitive sequence. It is our hope that this demonstration will stimulate further development of this approach to address significant problems in larval ecology. While an ideal assay would provide quantification as well as detection of planktonic species, detection alone would be sufficient for some applications. For example, the spread of an invading species could be monitored by detection of its arrival in new habitats or its occurrence in samples of ballast water. Detection could also be used to provide an efficient initial screen of plankton samples in which the species of interest occurs infrequently. After the species was detected, replicate samples could then be subjected to thorough analysis by microscopy or other methods.

Although detection of a planktonic species would be sufficient for some applications, it should also be possible to extend our approach to quantify the abundance or biomass of a target species. Rough estimates of larval density could be obtained by use of our detection assay to implement the 'most probable number' method, a method which is often used to estimate bacterial densities (Roser et al. 1987). Samples are progressively diluted to the point where no organisms are detected, and the dilution factor is then used to estimate the density of organisms in the initial sample. We are also investigating the use of competitive PCR (Wang et al. 1989) to estimate the biomass of Menippe in plankton samples. Competitive PCR includes an internal standard to control for variation in amplification efficiency, and thus addresses a common problem with field-collected samples.

Acknowledgements. Thanks are extended to Robert Bourgeois and Karen Strasser for field assistance, to Jeanine Ferrence, Richard Lance and Christine Spencer for critical review of this manuscript, and to the Louisiana Universities
Marine Consortium for logistic support. This work is a result of research sponsored by the NOAA National Sea Grant College Program Office, Department of Commerce, under Grant $\mathrm{R} / \mathrm{CFB}-21$. The US Government is authorized to produce and distribute reprints for governmental purposes notwithstanding any copyright notation that may appear hereon. Additional financial support was provided under Grant Nos. RII8820219 and (1992-1996)-ADP-02 from NSF/ EPSCoR program, Grant No. DE-FG02-97ER12220 from the US Department of Energy for studies of coastal endemism in the Gulf of Mexico, a Louisiana Board of Regents Doctoral Fellowship LEQSF (1995-00)-GF-28 (J.G.M.), and by the Graduate Student Organization of the University of Southwestern Louisiana.

\section{LITERATURE CITED}

Altschul SF, (ish W, Miller W, Myers EW, Lipman DJ (1990) Basic local alignment search tool. J Mol Biol 215:403-410

Bilodeau AL, Lankford WS, Kim TJ, Felder DL, Neigel JE (1999) An ultrasensitive method for detection of single crab larvae (Sesarma reticulatum) using PCR amplification of a highly repetitive DNA sequence. Mol Ecol 8: 683-684

Biodron-Metairon IF (1988) Morphological plasticity in laboratory-reared echinoplutei of Dendraster excentricus (Eschscholtz) and Lytechinus variegatus (Lamarck) in response to food conditions. J Exp Mar Biol Ecol 119:31-41

Coffroth MA, Mulawka JM III (1995) Identification of marine invertebrate larvae by means of PCR-RAPD speciesspecific markers. Limnol Oceanogr 40:181-189

Felger I. Hunt JA (1993) Detection and characterization of transposable elements. Method Enzymologia 224:322-334

Felger I, Sperlich D (1989) Cytological localization and organization of dispersed middle repetitive DNA sequences of Drosophila subobscura. Chromosoma 98:342-350

Finnegan DJ (1989) The I factor and I-R hybrid dysgenesis in Drosophila melanogaster. In: Berg DE, Howe MM (eds) Mobile DNA. American Society for Microbiology, Washington, DC, p 503-517

Fowler RF, Bonnewell V, Spann MS, Skinner DM (1985) Sequences of three closely related variants of a complex satellite DNA diverge at specific domains. J Biol Chem 260:8964-8972

Fritsch P, Reiseberg LH (1996) The use of random amplified polymorphic DNA (RAPD) in conservation genetics. In: Smith T, Wayne RK (eds) Molecular genetic approaches in conservation. Oxford University Press, Oxford, $p$ 54-73

Fuhrman JA, McCallum K, Davis AA (1992) Novel major archaebacterial group from marine plankton. Nature 356 : $148-149$

Fuhrman JA, Lee SH, Masuchi Y, Davis AA, Wilcox RM (1994) Characterization of marine prokaryotic communities via DNA and RNA. Microbial Ecol 28:133-145

Gaines SD, Bertness M (1993) The dynamics of juvenile dispersal: Why field ecologists must integrate. Ecology 74 : $2430-2435$

Gaines S, Roughgarden J (1985) Larval settlement rate-a leading determinant of structure in an ecological community of the marine intertidal zone. Proc Natl Acad Sci USA 82:3707-3711

Gaines S, Brown S, Roughgarden J (1985) Spatial variation in larval concentrations as a cause of spatial variation in settlement for the barnacle, Balanus glandula. Oecologia $67: 267-272$

Georgiev GP, Kramerov AP, Ryskov AP, Skyrabin KG, Lukanidin EM (1982) Dispersed repetitive sequences in eukary- 
otic genomes and their possible biological significance. Cold Spring Harbor Symp 47:1109-1121

Giovannoni SJ, Britschgi TB, Moyer CL, Field KG (1990) Genetic diversity in Sargasso Sea bacterioplankton. Nature 345:60-65

Graham DE, Skinner DM (1973) Homologies of repetitive DNA. sequences among Crustacea. Chromosoma 40:135-152

Grosberg RK, Levitan DR (1992) For adults only? Supply-side ecology and the history of larval biology. Trends Ecol Evol $7: 130-133$

Hardman N (1986) Structure and function of repetitive DNA in eukaryotes. Biochem $\sqrt{ }$ 234:1-12

LaMarca ME, Allison DP, Skinner DM (1981) Irreversible denaturation mapping of a pyrimidine-rich domain of a complex satellite DNA. J Biol Chem 256:6475-6479

Lewin R (1986) Supply-side ecology. Science 234:25-27

Lim EL (1996) Molecular identification of nanoplanktonic protists based on small subunit ribosomal RNA gene sequences for ecological studies. J Eukaryot Microbiol 43: $101-106$

Maniatis T, Fritsch EF, Sambrook I (1982) Molecular cloning: a laboratory manual. Cold Spring Harbor Laboratory Press, New York

Medeiros-Bergen DE, Olsen RR, Conroy JA, Kocher TD (1995) Distribution of holothurian larvae determined with speciesspecific genetic probes. Limnol Oceanogr 40:1225-1235

Neigel JE, Felder DL, Chlan CA, LaPorte R (1991) Cloning and screening of DNA probes for genetic studies in stone crabs (Decapoda: Xanthidae: Menippe). J Crustac Biol 11. $496-505$

Olsen RR, Runstadlet JA, Kocher TD (1991) Whose larvae? Nature 351:357-358

Palumbi SR, Martin A, Romano S, McMillan WO, Stice L, Grabowski G (1991) The simple fool's guide to PCR. University of Hawaii, Honolulu

Rehnstam AS, Backman S, Smith DC, Azam F, Hagstrom A (1993) Bloom of sequence-specific culturable bacteria in the sea. FEMS (Federation of European Microbiological Societies) Microbiol Ecol 102:161-166

Rheinsmith EL, Hinegardner R, Bachman K (1974) Nuclear DNA amounts in Crustacea. Comp Biochem Physiol B 48:343-348

Roberts JE (1995) A middle repetitive element from the genome of the stone crab, Menippe adina. Masters thesis, University of Southwestern Louisiana, Lafayette

Roser DJ, Bavor HJ, McKersie SA (1987) Application of mostprobable-number statistics to direct enumeration of microorganisms. Appl Environ Microbiol 53:1327-1332

Editorial responsibility: Otto Kinne (Editor),

Oldendorf/Luhe, Germany
Sanger F, Nicklen S, Coulson AR (1977) DNA sequencing with chain-terminating inhibitors. Proc Natl Acad Sci USA $74: 5463-5467$

Schneider-Broussard R, Felder DL, Chlan CA, Neigel JE (1998) Tests of phylogeographic models with nuclear and mitochondrial DNA sequence variation in the stone crabs, Menippe adina and $M$. mercenaria. Evolution 52: $1671-1678$

Shirley SM, Shirley TC, Rice SD (1987) Latitudinal variation in the dungeness crab. Cancer magister: zoeal morphology explained by incubation temperature. Mar Biol 95: $371-376$

Silberman JD, Walsh PJ (1992) Species identification of spiny lobster phyllosome larvae via ribosomal DNA analysis. Mol Mar Biol Biotechnol 1:195-205

Skinner DM, Fowler RF, Bonnewell $V$ (1982) Sites of divergence in the sequence of a complex satellite DNA and several cloned variants. Cold Spring Harb Sym 47 : $1151-1157$

Smith DL (1977) Marine coastal plankton and marine invertebrate larvae. Kendal/Hunt Publishing, Dubuque

Southern EM (1975) Detection of specific sequences by unequal crossover. Science 191:528-535

Spradling AC, Rubin GM (1981) Drosophila genome organization: conserved and dynamic aspects. Annu Rev Genet 15:219-264

Stringfellow LA, Fowler RF, LaMarca ME, Skinner DM (1985) Demonstration of remarkable sequence divergence in variants of a complex satellite DNA by molecular cloning. Gene 38:145-152

Todd CD (1998) Larval supply and recruitment of benthic invertebrates: Do larvae always disperse as much as we believe? Hydrobiologia 376:1-21

Wang AM, Doyle MV, Mark DF (1989) Quantification of mRNA by the polymerase chain reaction. Proc Natl Acad Sci USA 86:9717-9721

Ward DM, Weller R, Bateson MM (1990) 16S rRNA sequences reveal numerous uncultured microorganisms in a natural community. Nature 345:63-65

Williams JGK, Kubelik AR, Livak KJ, Rafalski JA, Tingey SV (1990) DNA polymorphisms amplified by arbitrary primers are useful as genetic markers. Nucleic Acids Res 18: $6531-6535$

Wilson DP, Armstrong FAJ (1961) Biological differences between seawaters: experiments in 1960. J Mar Biol Assoc UK 41:663-681

Young CM (1987) Novelty of supply-side ecology. Science $235: 415-416$

Submitted: October 6, 1998; Accepted: May 26, 1999

Proofs received from author(s): October 20,1999 